\title{
Production of Camel Milk Yoghurt: Physicochemical and Microbiological Quality and Consumer Acceptability
}

\author{
Obakeng Galeboe ${ }^{\mathrm{a}}$, Eyassu Seifu $^{\mathrm{a}^{*}}$, And Bonno Sekwhti-Monang ${ }^{\mathrm{a}}$ \\ a Department of Food Science and Technology, Botswana University of Agriculture and Natural Resources, \\ Private Bag 0027, Gaborone, Botswana \\ ${ }^{*}$ Corresponding author \\ eseifu@buan.ac.bw
}

Received: 23 August 2017; Published online: 18 October 2018

\begin{abstract}
The objectives of this study were to make yoghurt from camel milk and determine its physicochemical, microbiological and sensory qualities. The quality of camel milk yoghurt was compared with cow milk yoghurt and all parameters were analyzed following standard procedures. Yoghurt of acceptable consistency was made from camel milk using $1.2 \%$ gelatin, $5 \%$ bovine skim milk powder, $1.5 \mathrm{ml} / \mathrm{L}$ of calcium chloride, $40 \mathrm{ml} / \mathrm{L}$ of maple strawberry syrup and $6 \%$ yoghurt culture (YF-L811) and by incubating the milk at $42{ }^{\circ} \mathrm{C}$ for $18 \mathrm{~h}$. The average values for moisture, ash, syneresis, $\mathrm{pH}$, titratable acidity and total solids of camel milk yoghurt were $83.4 \%, 1.13 \%, 58 \%, 4.37,1.255 \%$ lactic acid and $16.7 \%$, respectively. The corresponding values for cow milk yoghurt were $80.6 \%, 0.71 \%, 56 \%, 4.67$, $0.865 \%$ lactic acid and $19.5 \%$, respectively. The titratable acidity of camel milk yoghurt was significantly higher $(\mathrm{P}<0.05)$ than cow milk yoghurt; however, no significant difference was observed between the two yoghurt types for the other parameters. Coliforms were not detected in both yoghurt types. The sensory analysis showed that cow milk yoghurt was more preferred by the panellists than camel milk yoghurt. Production of yoghurt from camel milk using the same procedure as for cow milk yoghurt proved to be difficult. Further research is called for to improve the acceptability of camel milk yoghurt using locally available and acceptable flavouring agents. Research needs to be conducted to optimize the operating parameters and standardize the production procedures of camel milk yoghurt in the future.
\end{abstract}

Keywords: Botswana; Camel milk yoghurt; Physicochemical properties; Microbial quality; Consumer acceptability

\section{Introduction}

Camels are very reliable milk producers during dry seasons and drought years when milk from cattle, sheep, and goats is scarce. In droughtstricken areas of the world, where continuous drought decimates cattle, sheep and goat populations, only the camel survives and continues to produce milk. Camel milk has an important role in food security and rural economy of arid zones of north and east Africa, the Middle East, central Asia, and the Indian subcontinent. In some regions, such as the horn of Africa, 10\% of the milk is derived from dromedary camels (Faye \& Bonnet, 2012).

Components of camel milk differ considerably from milk of ruminant animals (cows, sheep and goats). Camel milk has high concentrations of niacin and vitamin $\mathrm{C}$, and high water content especially during the hot summer months. Camels produce diluted milk in hot weather when water is scarce. Camel milk has low fat content and it 
creams less rapidly and less completely than cow milk (Farah, 2011). Camel milk has higher unsaturated fatty acids, lower saturated and short chain fatty acids and lower content of carotene than bovine milk (Claeys et al., 2014). The high vitamin $\mathrm{C}$ content of camel milk is of significant importance especially in arid and desert environments where green vegetables and fruits are not readily available. $\beta$-Lactoglobulin, the main whey protein of bovine milk, is not found in camel milk (Farah, 2011) and thus milk allergy which is usually associated with cow milk is not common with camel milk. Camel milk contains high proportions of antibacterial substances (AlOtaibi \& El-Demerdash, 2013) and it keeps for a longer period of time as compared with cow milk (Farah, 2011).

In recent years, interest in camel milk has grown among specific consumer groups in North America and Europe due to its potential medical benefits (Al Haj \& Al Kanhal, 2010; Mullaicharam, 2014; Sharma \& Singh, 2014). Camel milk has medicinal properties and contains protective proteins, which may have a possible role for enhancing the immune defence mechanism (Al-Otaibi \& El-Demerdash, 2013). Camel milk has been used to treat tuberculosis, dropsy, jaundice, and anaemia (Yagil, 1982; Hashim, Khalil, \& Habib, 2009). It has high insulin content (Agrawal, Beniwal, Sharma, et al., 2005; Shori, 2015) and it has traditionally been used to treat diabetes (Al-Numair, Chandramohan, \& Alsaif, 2011). Agrawal, Beniwal, Kochar, et al. (2005) reported that camel milk improved long-term glycaemic control and reduced insulin dose in patients with type-1 diabetes.

In traditional pastoral communities, camel milk is consumed predominantly fresh or after it turns sour. Camel milk does not coagulate easily and as a result it is difficult to make fermented dairy products such as cheese, yoghurt and butter from camel milk (Breulmann et al., 2017). The manufacturing of products like butter, ghee, yoghurt and cheese from camel milk is still not well developed and standardized (Farah, 1996). The main reason for the difficulty of product making from camel milk is due to the unique structural and functional properties of the milk components. Camel milk contains low amounts of kappa casein resulting in a weak casein network that is destroyed during cutting and the loss of dry matter of cheese to the whey (Ramet, 2001). Processing of set-type yoghurt by use of gelatin or alginate plus calcium with acceptable sensory quality was reported for camel milk (Hashim et al., 2009). Reports also indicate the possibility of production of cheese from camel milk (Mehaia, 1993; Khan, Athar, \& Aslam, 2004). However, these reports indicate the need for more research to improve the quality, efficiency and the yield of dairy products from camel milk.

Production of yoghurt from cow milk is well established. The procedure for yoghurt production from cow milk involves pasteurization of the milk at $85{ }^{\circ} \mathrm{C}$ for $30 \mathrm{~min}$, cooling the heat treated milk to $42{ }^{\circ} \mathrm{C}$, addition of thermophilic yoghurt culture, addition of stabilizers and sweeteners depending on the type of yoghurt produced, and incubating the milk at $42{ }^{\circ} \mathrm{C}$ for $4 \mathrm{~h}$ (Tamime $\&$ Robinson, 2000). However, production of yoghurt from camel milk using the same technology and procedure as for cow milk proved to be difficult due to the inherent characteristics of camel milk. In recent years, attempts have been made by different researchers to make yoghurt from camel milk (Hashim et al., 2009; Al-Zoreky \& AlOtaibi, 2015; Ibrahem \& El Zubeir, 2016). However, the results reported so far are different from one another and sometimes conflicting. This suggests that the procedure for yoghurt production from camel milk is not yet established and more research needs to be done in order to standardize the manufacturing procedure.

In Botswana, camels are kept in Tsabong which is a semi-arid region in Kgalagadi District. They are kept in an enclosed park known as Tsabong Ecotourism Camel Park. The camels are under the care of the local community and the Botswana Tourism Organization oversees the overall management of the park. Despite the potential of camels in Botswana, no research has been carried out on camels or their products to date. Camels kept in Tsabong are mainly used for tourism (riding) purposes. The milk produced is consumed raw and is not processed into value-added products. To date no attempt has been made to make products from camel milk in Botswana.

Yoghurt production from camel milk would diversify dairy products in the market and in- 
crease income of camel keepers and improve their livelihoods. This study was conducted to develop yoghurt from camel milk and determine the physicochemical and microbiological properties and consumer acceptability of camel milk yoghurt.

\section{Materials and Methods}

\subsection{Description of the study area}

Tsabong is the administrative centre of the Kgalagadi District located in south-western Botswana. The human population of the area was 8939 according to the 2011 census. The geographical coordinates of Tsabong are $26^{\circ} 3$ ' 0 " South, 22 27' 0" East. The study area, Tsabong Ecotourism Camel Park, is found in this region and is located at a distance of $520 \mathrm{~km}$ from the capital city Gaborone and $10 \mathrm{~km}$ north of Tsabong town and comprises a fenced area of 3200 hectares. The area is characterized by poor and unreliable rainfall with an annual precipitation of less than $250 \mathrm{~mm}$ and with an average ambient temperature of above $35{ }^{\circ} \mathrm{C}$ during summer and less than $2{ }^{\circ} \mathrm{C}$ in winter (Kgaudi, 2014). The area has sparsely distributed vegetation dominated by Acacia and Grewia species and some species of grass.

\subsection{Sampling and milk sample collection}

Milk samples were collected from camels kept in Tsabong Ecotourism Camel Park. Milk from different lactating camels that were at their sixth month of lactation was pooled together and a total of seven litres of milk was sampled and placed into a sterile container. Prior to hand milking the camels, the milkers washed their hands in order to prevent contamination of the milk.

The milk samples were then kept in a cool box containing packs of ice blocks and transported to Botswana University of Agriculture and Natural Resources Laboratory immediately after collection and kept at $4{ }^{\circ} \mathrm{C}$ in a refrigerator pending laboratory analysis. In the laboratory, the milk sample was divided into five lots of one litre each.
Cow milk samples were used for production of yoghurt as controls.

\subsection{Yoghurt preparation from camel milk}

After a number of preliminary trials, the following formulation was used to make yoghurt samples for physicochemical, microbiological and sensory analyses. Prior to yoghurt making, all equipment used was thoroughly washed and sterilized by boiling in hot water for 1 hour in order to kill vegetative cells of microorganisms on the surface of the equipment. Before pasteurization, 12 grams of gelatin and 50 grams of bovine skim milk powder were weighed separately and added into the milk (1 L) and mixed. The milk was then pasteurised at $85{ }^{\circ} \mathrm{C}$ for $30 \mathrm{~min}$ in a thermostatically controlled water bath. The milk was then cooled to $42{ }^{\circ} \mathrm{C}$, followed by addition of $1.5 \mathrm{ml}$ $/ \mathrm{L}(40 \% \mathrm{w} / \mathrm{v})$ of food-grade calcium chloride, 40 $\mathrm{ml} / \mathrm{L}$ of maple strawberry maple syrup (Tongaat Hullets Sugar, South Africa) and 6\% commercial yoghurt culture (YF-L811 thermophilic yoghurt culture, Chr. Hansen, Denmark). The inoculated milk sample (1 L) was then divided into three lots of $333 \mathrm{ml}$ each, incubated at $42{ }^{\circ} \mathrm{C}$ for 18 hours and stored at $4{ }^{\circ} \mathrm{C}$ overnight before testing. The same procedure was followed for the production of cow milk yoghurt except that $25 \mathrm{~g}$ of skimmed milk powder was used instead of 50 grams and it was incubated for 4 hours at $43{ }^{\circ} \mathrm{C}$. Figure 1 shows the flow diagram of the procedure used for production of the yoghurt samples.

\subsection{Physicochemical properties}

\section{Moisture content}

The moisture content of the yoghurt samples was determined according to the method specified by Association of Official Analytical Chemists (Association of Official Analytical Chemists, 1995). Ten grams of yoghurt sample were placed in a dried and weighed moisture dish which was then placed in air oven for 1 hour at $105{ }^{\circ} \mathrm{C}$. The moisture dish was then removed and placed in a desiccator to cool and then weighed. The loss in weight was regarded as moisture content which 


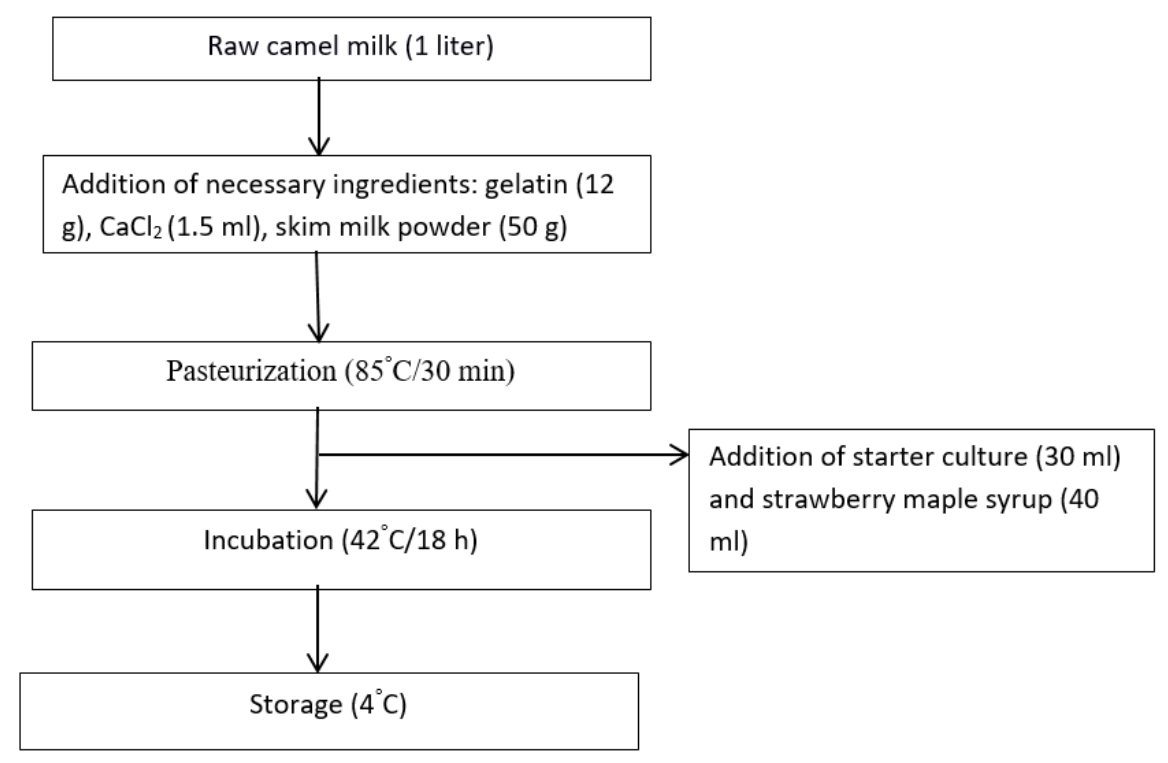

Figure 1: Production steps of camel milk yoghurt

was calculated using the following formula: Moisture content $(\%)=$

$$
\frac{\text { weight of fresh sample }- \text { weight of dry sample }}{\text { weight of fresh sample }} \times
$$$$
100
$$

\section{Total solids}

The weight of the residue obtained from moisture content analysis was used to compute the total solids using the formula below (Association of Official Analytical Chemists, 1995):

Total solids $(\%)=\frac{(\text { dry yoghurt })}{\text { weight of the sample }} \times 100$

\section{Titratable acidity}

The titratable acidity of yoghurt was determined using the method described by Richardson (1985). Yoghurt sample (9 g) was weighed in $100 \mathrm{ml}$ Erlenmeyer flask and $20 \mathrm{ml}$ of fresh distilled water was added to it and then titrated against $0.1 \mathrm{~N} \mathrm{NaOH}$ after adding 3-5 drops of $1 \%$ phenolphthalein solution until persistent (30 sec.), faint pink colour was observed. The titratable acidity was then expressed as per- centage of lactic acid using the following formula:

Lacticacid $(\%)=\left[\frac{\left(m l \frac{N}{10} \text { alkali } \times 0.009\right)}{m l \text { of sample used }}\right] \times 100$

\section{pH}

For determination of $\mathrm{pH}$ of yoghurt samples, a digital electronic pH meter (Orion Star A111 Benchtop pH Meter, Thermo Scientific USA) was used after calibrating it using standard buffer solutions of $\mathrm{pH} 4$ and 7 . The $\mathrm{pH}$ was then measured by inserting the glass electrode into the sample in a beaker and the reading was taken when the displayed value was steady.

\section{Ash content}

The ash content of yoghurt samples was determined according to the Association of Official Analytical Chemists (1995) method No.945.46. Using the dried yoghurt samples from the determination of total solids content, a sample weighing approximately $3 \mathrm{~g}$ was measured and put in a crucible, placed into a muffle furnace and ignited at $\leq 550{ }^{\circ} \mathrm{C}$ until ash was carbon free. Then, it was placed in a desiccator for 
cooling and re-weighed. The initial and final weights of the sample were recorded. The ash weight was divided by the original sample weight and expressed in percent. The ash content was calculated using the following formula:

Ash $(\%)=\frac{\text { weight of residue }}{\text { weight of sample }} \times 100$

\section{Syneresis}

Syneresis (whey separation) was determined according to Celik and Bakirci (2003). Five ml of yoghurt was placed into a test tube and centrifuged at $5000 \mathrm{rpm}$ for $20 \mathrm{~min}$ at $4{ }^{\circ} \mathrm{C}$. After centrifugation, the test tube was then kept for 1 min before measuring the volume of separated whey. The rate of syneresis (\%) was expressed as volume of separated whey per $100 \mathrm{ml}$ of yoghurt.

\subsection{Microbiological analysis}

The microbiological quality tests conducted included coliform count (CC) and yeast and mould count (YMC). Violet Red Bile Agar (VRBA) (Oxoid, England) was used for CC and chloramphenicol agar (Merck, South Africa) was used for YMC. Yoghurt samples for microbiological analysis were prepared according to the method described by Richardson (1985). From a thoroughly mixed sample, $11 \mathrm{~g}$ of yoghurt was weighed into a $100 \mathrm{ml}$ Schott bottle and mixed with $90 \mathrm{ml}$ of peptone water $\left(40^{\circ} \mathrm{C}\right)$. The content was then mixed (10 min) until a homogenous dispersion was obtained, and then this 1:10 dilution was used for YMC and CC.

\section{Coliform count}

Coliform count was determined according to the method described by Richardson (1985) and Haddad, Al-Qudah, Abu-Romman, Obeidat, and El-Qudah (2017) using Violet Red Bile Agar (VRBA). From the 1:10 dilution of yoghurt, $1 \mathrm{ml}$ sample was pour plated on duplicate Petri dishes and then VRBA was added (15-20 ml) onto each of them. Plates were then incubated at $30{ }^{\circ} \mathrm{C}$ for 24 hours. Typical dark red colonies $(>0.5 \mathrm{~mm}$ in diameter) were considered as coliforms (Richardson, 1985).

\section{Yeast and mould count}

Yeast and mould count was determined as reported by Richardson (1985) using chloramphenicol agar. From the 1:10 dilution, $0.1 \mathrm{ml}$ sample was placed on the surface of the chloramphenicol agar and evenly distributed using the streak plate technique. The plates were then incubated at $25{ }^{\circ} \mathrm{C}$ for 5 days. Yeast and mould count per gram of yoghurt was reported (Richardson, 1985).

\subsection{Sensory evaluation}

Sensory evaluation of yoghurt samples was carried out according to the method described by Barnes, Harper, Bodyfelt, and Mcdaniel (1991) using 25 consumer panellists consisting of 15 males and 10 females. Testing was conducted in the Food Processing Laboratory of Botswana University of Agriculture and Natural Resources (BUAN). Consumers were asked to write their preference (liking) of the yoghurt samples for the sensory attributes colour, aroma, sweetness, sourness, mouth feel and overall acceptability. Consumer panellists (BUAN students and staff) were selected based on their experience of yoghurt consumption. Yoghurt samples were served at temperature of less than $7^{\circ} \mathrm{C}$ (Tamime, 2006) and a sample size of at least $40 \mathrm{ml}$ of yoghurt was served in clear shot glasses. The yoghurt samples were presented in a randomised order. Panellists were asked to evaluate the sensory attributes of yoghurt, using the 9 point hedonic scale $(1=$ dislike extremely, $5=$ neither like nor dislike, $9=$ like extremely). Spring water was provided in disposable cups for cleansing their palates between samples. Prior to sensory evaluation, panellists read an explanation about the purpose of the study and gave their informed consent to participate in the sensory evaluation.

\section{7 $\quad$ Statistical analysis}

Comparison was made between yoghurt samples made from camel milk and cow milk for the parameters considered. The data generated was analysed using Student's t-test. The microbial 
count data were $\log _{10}$ transformed before statistical analysis.

\section{Results and Discussions}

\subsection{Yoghurt making}

A number of preliminary trials were conducted in order to come up with a formulation that resulted in production of yoghurt of acceptable consistency from camel milk. In the initial trial, $0.6 \%$ gelatin and $2.5 \%$ milk solids-not-fat (MSNF) were added into camel milk and the mixture was pasteurized at $85{ }^{\circ} \mathrm{C}$ for $30 \mathrm{~min}$ and then cooled to $43{ }^{\circ} \mathrm{C}$. This was followed by addition of $2 \%$ yoghurt culture (YF-L811 thermophilic yoghurt culture) and the milk was incubated at $43{ }^{\circ} \mathrm{C}$ for $4 \mathrm{~h}$ as recommended by Hashim et al. (2009). This did not result in the coagulation of the milk. In a second trial, $0.5 \%$ xanthan gum was added as a stabilizer (as suggested by Al-Zoreky and AlOtaibi (2015)) in addition to $0.6 \%$ gelatin and yoghurt was made following the same procedure as above. The xanthan gum did not dissolve completely and formed lumps in the milk and the milk had thin and watery consistency. In a third trial, $2 \%$ gelatin and $7.5 \%$ MSNF were added into camel milk and the mixture was pasteurized at $85{ }^{\circ} \mathrm{C}$ for $30 \mathrm{~min}$ and then cooled to 43 ${ }^{\circ} \mathrm{C}$. The cooled milk sample was inoculated with $6 \%$ yoghurt culture, $50 \mathrm{ml} / \mathrm{L}$ maple strawberry syrup and $1.5 \mathrm{ml} / \mathrm{L}$ food-grade calcium chloride and the milk was incubated at $43{ }^{\circ} \mathrm{C}$ for $22 \mathrm{~h}$. This resulted in a very thick gel that was difficult to sample and analyze for parameters such as syneresis and was not appealing for sensory analysis.

Finally, yoghurt of acceptable appearance and consistency was obtained by adding $1.2 \%$ gelatin and $5 \%$ skim milk powder into the camel milk and pasteurizing the mixture at $85^{\circ} \mathrm{C}$ for $30 \mathrm{~min}$. The pasteurized milk was cooled to $42{ }^{\circ} \mathrm{C}$ and 1.5 $\mathrm{ml} / \mathrm{L}$ of food-grade calcium chloride, $40 \mathrm{ml} / \mathrm{L}$ of maple strawberry syrup and $6 \%$ commercial yoghurt culture were added and the milk was then incubated at $42{ }^{\circ} \mathrm{C}$ for $18 \mathrm{~h}$. The resulting yoghurt had a fairly thick consistency although it was less viscous and not as firm as cow milk yoghurt. The product was more like drinking yo- ghurt. This observation was in agreement with the findings of Ibrahem and El Zubeir (2016) who reported that yoghurt made from camel milk was less firm (had fluid-like texture) and was suitable for use as a drinking yoghurt. In the present study, $1.2 \%$ gelatin was used as a stabilizer and this is agreeed with Ibrahim and Khalifa (2015) who recommended that $1.5 \%$ gelatin can be added to camel milk to stabilize the texture of camel milk yoghurt without affecting the overall acceptability of the yoghurt.

Hashim et al. (2009) reported that acceptable camel milk yoghurt can be produced by dissolving milk solids-not-fat $(2.5 \%)$ and stabilizer $(0.6 \%$ gelatin or $0.75 \%$ sodium alginate (ALG) and $0.075 \%$ calcium chloride in camel milk and pasteurizing the mixture at $85^{\circ} \mathrm{C}$ for $30 \mathrm{~min}$ and incubating it at $43{ }^{\circ} \mathrm{C}$ for $4 \mathrm{~h}$ after inculcating the cooled milk with commercial yoghurt culture. They indicated that addition of $1 \%$ gelatin or $0.75 \%$ ALG $+0.075 \%$ Ca resulted in camel milk yoghurt with the highest intensities for firmness and body. They also reported that addition of $0.75 \%$ sodium alginate $+0.075 \%$ calcium chloride produced camel milk yoghurt with acceptable sensory attributes similar to cow milk yoghurt.

Al-Zoreky and Al-Otaibi (2015) made camel milk yoghurt using $6 \%$ stabilizers (carboxymethyl cellulose, pectin, gum acacia or alginate), which were added to pasteurized $\left(85^{\circ} \mathrm{C} / 20 \mathrm{~min}\right)$ camel milk and then heated for $10 \mathrm{~min}$ at $85{ }^{\circ} \mathrm{C}$ after thorough mixing. The pasteurized camel milk formulations were cooled to $45{ }^{\circ} \mathrm{C}$, inoculated with $2 \%(\mathrm{v} / \mathrm{v})$ commercial yoghurt culture and incubated at $42 \pm 1{ }^{\circ} \mathrm{C}$ for $6 \mathrm{~h}$. They reported that stabilizers did not improve the consistency and coagulum of camel milk yoghurt compared with cow milk yoghurt. They also indicated that camel milk yoghurt containing $0.6 \%$ alginate $+0.06 \% \mathrm{CaCl}_{2}$ showed higher rate $(33.5 \%)$ of syneresis (whey separation) as compared with cow milk yoghurt (23.8\%) indicating a weaker water-holding capacity.

Camel milk took longer time to ferment as compared to cow milk. The present observation contradicts the findings of Hashim et al. (2009) who reported that use of $1 \%$ gelatin and $0.075 \%$ calcium chloride results in camel milk yoghurt with firm body when incubated at $43{ }^{\circ} \mathrm{C}$ for $4 \mathrm{~h}$. In 
the current study, camel milk did not form a coagulum/gel after 4 hours of incubation at $43{ }^{\circ} \mathrm{C}$ irrespective of the level of ingredients used. However, this observation was in line with the findings of Ibrahem and El Zubeir (2016) who reported that camel milk takes longer time $(17 \mathrm{~h})$ to coagulate as compared with sheep milk. Similarly, Attia, Kherouatou, and Dhouib (2001) concluded that dromedary milk appears less favorable for lactic fermentation, because the activity of the inoculated lactic starter was lower in camel milk than in bovine milk. Generally, more research needs to be conducted to optimize the operating parameters and standardize the production procedures of camel milk yoghurt in the future.

\subsection{Physicochemical properties}

\section{pH and acidity}

Physical properties of yoghurt play an important role in determining its quality. Table 1 depicts the physical properties of yoghurt made from camel milk and cow milk. The sourness and refreshing taste of yoghurt are mainly attributed to its acidity. The average titratable acidity of camel milk yoghurt observed in the present study was higher than the value $(0.78 \%)$ reported by Bhagiel, Musatafa, Tabidi, and Ahmed (2015) for camel milk. Al-Zoreky and Al-Otaibi (2015) reported a $\mathrm{pH}$ value of 4.59-4.63 and a titratable acidity of $0.71-0.87 \%$ lactic acid for camel milk yoghurt produced in Saudi Arabia. On the other hand, Hashim et al. (2009) reported a $\mathrm{pH}$ value ranging from 4.3 to 4.5 and a titratable acidity ranging from 0.98 to $1.16 \%$ for camel milk yoghurt produced with added gelatin, alginates and calcium chloride. In the present study, the titratable acidity of camel milk yoghurt was significantly higher $(\mathrm{P}<0.05)$ than that of cow milk yoghurt (Table 1). Camel milk yoghurt had a lower $\mathrm{pH}$ (4.37) which contributed to its higher acidity compared to cow milk yoghurt which had a pH of 4.67. Ibrahim and Khalifa (2015) reported that addition of stabilizer (gelatin and mono \& diglycerides of fatty acids) caused highest acidity and lowest $\mathrm{pH}$ of camel milk yoghurt compared with those which did not have stabilizer. This was also observed by Kavas (2016) who found a significant increase in acidity when xanthum gum was used as a stabilizer in camel milk yoghurt.

\section{Moisture}

The average moisture contents of camel and cow milk yoghurt are indicated in Table 1 . The moisture content of camel milk yoghurt observed in the present study was lower than that reported by Bhagiel et al. (2015) and Eissa, Mohamed, Yagoub, and Babiker (2010) for camel milk yoghurt which was $88.17 \%$ and $87.71 \%$, respectively. It was also lower than the value of $87.71 \%$ reported by Eissa, Yagoub, Babiker, and Ahmed (2011) for the moisture content of camel milk yoghurt produced in Sudan. These differences in moisture can be attributed to seasonal variations in milk composition and availability of drinking water for camels (Bhagiel et al., 2015). The moisture content of the two yoghurt samples in the present study was not significantly $(\mathrm{P}>0.05)$ different.

\section{Syneresis}

Syneresis is an important defect in yoghurt. It is defined as the separation of whey (serum) from the coagulum in yoghurt and is related to shrinkage of the gel (Sahan, Yasar, \& Hayaloglu, 2008). This quality defect occurs in yoghurt due to low total solids, over acidification, mechanical shaking of the gel network, insufficient denaturation of whey proteins, incompatibility of dairy and non-dairy ingredients (inappropriate amount and/or type of stabilizer), too high incubation temperature or too low acidification ( $\mathrm{pH}>4.6)$ (Chandan \& A., 2013). Syneresis can limit the shelf life and acceptability of yoghurt because of the undesirable appearances it causes. If yoghurt is subjected to a high degree of syneresis, its shelf life could be reduced as the gel formed could easily expel whey from the gel matrix leading to a suspension of yoghurt materials in whey within short period of time (Habtegebriel \& Admassu, 2016). Yoghurt with high degree of syneresis is not liked by consumers. No significant difference $(\mathrm{P}>0.05)$ in syneresis was observed between camel milk and cow milk yoghurt (Table 1). The syneresis value observed 
Table 1: Physicochemical properties of yoghurt made from camel and cow milk

\begin{tabular}{lll}
\hline Variable & Camel milk yoghurt & Cow milk yoghurt \\
\hline Moisture (\%) & $83.40 \pm 0.59$ & $80.60 \pm 2.32$ \\
Total solids (\%) & $16.65 \pm 0.06$ & $19.45 \pm 2.32$ \\
Ash (\%) & $1.13 \pm 0.23$ & $0.71 \pm 0.09$ \\
Syneresis (\%) & $58.00 \pm 2.83$ & $56.00 \pm 1.41$ \\
pH & $4.37 \pm 0.01$ & $4.67 \pm 0.01$ \\
Titratable acidity (\%lactic acid) & $1.255 \pm 0.021^{a}$ & $0.865 \pm 0.007^{b}$ \\
\hline
\end{tabular}

Means with different superscript letters in a row are significantly different $(\mathrm{P}<0.05)$; Values in the table are means plus standard deviations of three samples

for camel milk yoghurt in the present study was higher than the value $(33.5 \%)$ reported by AlZoreky and Al-Otaibi (2015). The difference in syneresis observed between the current study and that reported by Al-Zoreky and Al-Otaibi (2015) could be attributed to the difference in the type of stabilizer used which was gelatin in the former and sodium alginate in the latter study. The type and level of stabilizer used influence the degree of synersis in yoghurt Ibrahim and Khalifa (2015). Syneresis decreases with increase in stabilizer addition (Kiros, Seifu, Bultosa, \& Solomon, 2016). Similarly, Ibrahim and Khalifa (2015) reported that addition of stabilizers significantly decreased syneresis, and increased viscosity and water holding capacity of camel milk yoghurt $(\mathrm{P} \leq 0.05)$.

\section{Ash}

The average ash contents of camel milk yoghurt and cow milk yoghurt are indicated in Table 1. The ash content of camel milk yoghurt observed in the present study was higher than the value of $0.84 \%$ reported by Bhagiel et al. (2015) and $0.71 \%$ reported by Eissa et al. (2011) for camel milk yoghurt produced in Sudan. It was also higher than the value $(0.99 \%)$ reported by Ibrahem and El Zubeir (2016) for ash content of camel milk yoghurt. The ash content is an index of the mineral content of milk or yoghurt, which is needed for bone development, teeth formation and body functions (Bibiana \& Joseph, 2014). The ash content of camel milk yoghurt was higher than cow milk yoghurt (Table 1). The results indicate that camel milk yoghurt is a good source of minerals.

\section{Total solids}

The average total solids (TS) content of camel milk yoghurt observed in the present study was higher than that reported by Bhagiel et al. (2015) and Bashir (2009), which were $11.83 \%$ and $11.3 \%$, respectively. It was also higher than the values $(12.2 \%$ and $9.24 \%$ ) reported by Eissa et al. (2011) and Ibrahem and El Zubeir (2016), respectively, for TS of camel milk yoghurt. The TS content of yoghurt is influenced by the TS of the raw material (milk) from which it is produced. The total solids content of camel milk varies with season and it tends to be lower in the hot season as the water content of the camel milk increases during this season for the nourishment of young calves Bhagiel et al. (2015). The high amount of total solids observed in this study could be attributed to the addition of skim milk powder during the preparation of the yoghurt. For yoghurt manufacture, the solids content of the milk is usually increased to $16 \%$. Increasing the solids content improves the nutritional value of yoghurt, makes it easier to produce firmer yoghurt and improves stability.

\subsection{Microbiological quality}

Presence of coliforms in yoghurt suggests unsanitary conditions during processing (Eissa et al., 2010). In the present study, coliforms were not detected in both yoghurt types (Table 2). This agreed with the findings of Eissa et al. (2011) who reported absence of coliforms in camel milk 
yoghurt. The absence of coliforms in the present study could be attributed to the high hygienic conditions followed in the laboratory that prevented post-processing contamination.

Yeasts and moulds are major causes of spoilage of yoghurt and other fermented dairy products in which the low $\mathrm{pH}$ provides a selective environment for their growth. yoghurt produced under good manufacturing practices should contain no more than 10 yeast cells/g and should have a shelf life of $3-4$ weeks at $5{ }^{\circ} \mathrm{C}$ (Ledenbach \& Marshall, 2009). They also stated that yoghurts having initial counts of $>100 \mathrm{cfu} / \mathrm{g}$ tend to spoil quickly. Yeasty and fermented off-flavours and gassy appearance are often detected in yoghurt when yeasts grow to $10^{5}-10^{6} \mathrm{cfu} / \mathrm{g}$ (Ledenbach \& Marshall, 2009). Total yeast and mould count recommended in yoghurt is $<10 \mathrm{cfu} / \mathrm{g}$ (Mostert \& Jooste, 2002). The yeast and mould count (YMC) of camel milk yoghurt observed in the present study (Table 2) was in line with the findings of Eissa et al. (2011) who reported YMC of $6.5 \times 10^{4} \mathrm{cfu} / \mathrm{g}$ for camel milk yoghurt produced in Sudan.

\subsection{Sensory analysis}

Results of the sensory analysis of the yoghurt samples are indicated in Table 3. Camel milk yoghurt had the lowest rating compared with cow milk yoghurt for all sensory attributes except for sourness. A significant difference $(\mathrm{P}<0.05)$ was observed between camel milk and cow milk yoghurts for colour, aroma, sweetness, mouth feel and overall acceptability. Cow milk yoghurt had higher scores for all these parameters. The sourness score for camel milk yoghurt was numerically higher than that of cow milk yoghurt (Table 3 ) and this corresponded with the higher acidity (lower $\mathrm{pH}$ ) observed in camel milk yoghurt (Table 1). Plain yoghurt made from camel milk in the preliminary trials had a pungent smell and salty taste and this was the reason for inclusion of maple strawberry syrup in the production of the experimental yoghurt samples. This observation agreed with the findings of Eissa et al. (2011) who reported that camel milk yoghurt had lower consumer acceptability compared with cow milk yoghurt. They attributed the low acceptability of camel milk yoghurt to the high concentration of salt in camel milk. In the present study, inclusion of maple strawberry syrup improved the aroma and flavour of the camel milk yoghurt; however, even then the consumer acceptability scores for sensory attributes of the camel milk yoghurt were significantly lower than that of cow milk yoghurt. This suggested the need for further research aimed at improving the sensory quality of camel milk yoghurt using various indigenous fruits and other ingredients that are well accepted by the community.

Most of the panellists were able to notice a salty taste in the camel milk yoghurt which is not common in cow milk yoghurt. Also the panelists noticed that the yoghurt made from camel milk lacked firm texture, which was in agreement with the findings of Ibrahem and El Zubeir (2016) and Hassan, El Zubeir, and Babiker (2007). Attia et al. (2001) reported that fermented dromedary milk did not produce a curd structure but a few dispersed, small casein fragments at the surface and a film or firm gel at the bottom of the vessel. The low overall acceptability of camel milk yoghurt observed in the present study was in line with earlier reports. Ibrahem and El Zubeir (2016) reported low overall acceptability of camel milk yoghurt compared with yoghurt made from sheep milk or a mixture of sheep and camel milk. Similarly, Hashim et al. (2009) reported that yoghurt made from camel milk had the lowest ratings for all the sensory attributes and addition of gelatin and sodium alginate significantly improved acceptability of camel milk yoghurt. Also Al-Saleh, Metwalli, and Ismail (2011) reported that flavour scores of frozen yoghurt made from camel milk constituents were significantly lower $(\mathrm{P}<0.05)$ than those made from cow milk.

\section{Conclusion}

Yoghurt of acceptable consistency was made from camel milk using $1.2 \%$ gelatin, $5 \%$ skim milk powder, $1.5 \mathrm{ml} / \mathrm{L}$ of calcium chloride, 40 $\mathrm{ml} / \mathrm{L}$ of maple strawberry syrup as a flavouring agent and $6 \%$ yoghurt culture and by incubating the milk at $42{ }^{\circ} \mathrm{C}$ for $18 \mathrm{~h}$. The results showed that camel milk yoghurt and cow milk yoghurt had comparable physicochemical and microbio- 
$60 \mid$ Galeboe et al.

Table 2: Microbial counts (cfu/g) of yoghurt made from camel and cow milk

\begin{tabular}{lll}
\hline Count & Camel milk yoghurt & Cow milk yoghurt \\
\hline Yeast and mould & $1.4 \times 10^{4}$ & $2.8 \times 10^{4}$ \\
Coliforms & ND & ND \\
\hline
\end{tabular}

No significant difference $(\mathrm{P}>0.05)$ was observed in yeast and mould counts between the two yoghurt types; ND = not detected Values in the table are means plus standard deviations of three samples

Table 3: Sensory quality of yoghurt made from camel and cow milk $(\mathrm{n}=25)$

\begin{tabular}{lll}
\hline Sensory attribute & Camel milk yoghurt & Cow milk yoghurt \\
\hline Colour & $5.80 \pm 1.23^{a}$ & $7.00 \pm 0.91^{b}$ \\
Aroma & $5.50 \pm 1.30^{a}$ & $7.60 \pm 0.75^{b}$ \\
Sweetness & $5.60 \pm 1.20^{a}$ & $6.30 \pm 0.85^{b}$ \\
Sourness & $6.00 \pm 1.26$ & $5.70 \pm 1.32$ \\
Mouth feel & $3.50 \pm 1.17^{a}$ & $6.30 \pm 1.20^{b}$ \\
Overall acceptability & $4.10 \pm 1.03^{a}$ & $6.70 \pm 1.59^{b}$ \\
\hline
\end{tabular}

Means with different superscript letters in a row are significantly different $(\mathrm{P}<0.05)$;

$\mathrm{n}=$ total number of panellists. Values are means and standard deviations

logical properties. However, cow milk yoghurt was more preferred than camel milk yoghurt. Production of yoghurt from camel milk using the same procedure as for cow milk yoghurt is difficult. Thus, more research needs to be conducted to optimize the operating parameters and standardize the production procedures of camel milk yoghurt in the future. The low consumer acceptability of camel milk yoghurt calls for further research to improve the acceptability of camel milk yoghurt using locally available and acceptable flavouring agents such as indigenous fruits.

\section{Acknowledgements}

The authors would like to thank Tsabong Ecotourism Camel Park workers for their assistance during the camel milk sample collection. We would also like to extend our appreciation to Botswana Tourism Organization for giving us permission to collect camel milk samples from the park. This study was funded by the Department of Tertiary Education of Botswana.

\section{References}

Agrawal, R. P., Beniwal, R., Kochar, D. K., Tuteja, F. C., Ghorui, S. K., Sahani, M. S., \& Sharma, S. (2005). Camel milk as an adjunct to insulin therapy improves longterm glycemic control and reduction in doses of insulin in patients with type-1 diabetes. a 1 year randomized controlled trial. Diabetes Research And Clinical Practice, 68(2), 176-177. doi:10.1016/j.diabres.2004. 12.007

Agrawal, R. P., Beniwal, R., Sharma, S., Kochar, D. K., Tuteja, F. C., Ghorui, S. K., \& Sahani, M. S. (2005). Effect of raw camel milk in type 1 diabetic patients: 1 year randomised study. Journal Of Camel Practice And Research, 12(1), 27-31.

Al Haj, O. A. \& Al Kanhal, H. A. (2010). Compositional, technological and nutritional aspects of dromedary camel milk. International Dairy Journal, 20(12), 811-821. doi:10.1016/j.idairyj.2010.04.003

Association of Official Analytical Chemists. (1995). Official methods of analysis (16th ed.). Washington DC.: Association of Official Analytical Chemists.

\begin{tabular}{l|l|l|l} 
IJFS & October $2018 \mid$ Volume 7 & pages 51-63
\end{tabular} 
Quality aspects of camel milk yoghurt $\mid 61$

Attia, H., Kherouatou, N., \& Dhouib, A. (2001). Dromedary milk lactic acid fermentation: microbiological and rheological characteristics. Journal Of Industrial Microbiology and Biotechnology, 26(5), 263-270. doi:10. 1038/sj.jim.7000111

Barnes, D. L., Harper, S. J., Bodyfelt, F. W., \& Mcdaniel, M. R. (1991). Prediction of consumer acceptability of yogurt by sensory and analytical measures of sweetness and sourness. Journal Of Dairy Science, 74 (11), 3746-3754. doi:10.3168/jds.S0022$0302(91) 78566-4$

Bashir, A. Y. M. (2009). Effect of gum arabic on enzymatic coagulation of camel milk (Doctoral dissertation, Sudan University of Science \& Technology).

Bhagiel, I., Musatafa, E. A., Tabidi, M. M., \& Ahmed, M. E. M. (2015). Comparison between the physiochemical attributes of yogurt processed from camel milk and that processed from cow milk and the effect of storage. World Journal of Pharmacy and Pharmaceutical Sciences, 4 (8), 1530-1540.

Bibiana, I. \& Joseph, A., S. an Julius. (2014). Physicochemical, microbiological and sensory evaluation of yoghurt sold in makurdi metropolis. African Journal of Food Science and Technology, 5(6), 129-135. doi:10. 14303 /ajfst.2014.052

Breulmann, M., Böer, B., Wernery, U., Wernery, R., El Shaer, H., Alhadrami, G., ... Norton, J. (2017). The camel from tradition to modern times. a proposal towards combating desertification via the establishment of camel farms based on fodder production from indigenous plants and halophytes. United Arab Emirates: UNESCO Doha Office.

Celik, S. \& Bakirci, I. (2003). Some properties of yoghurt produced by adding mulberry pekmez (concentrated juice). International Journal Of Dairy Technology, 56(1), 2629. doi:10.1046/j.1471-0307.2003.00070.x

Chandan, R. C. \& A., K. (2013). Manufacturing yogurt and fermented milks. (2nd ed.) USA: Wiley-Blackwell. Retrieved from https : / / www . wiley . com / en bw / Manufacturing + Yogurt + and +
Fermented + Milks , +2nd + Edition - p 9781119967088

Claeys, W. L., Verraes, C., Cardoen, S., De Block, J., Huyghebaert, A., Raes, K., ... Herman, L. (2014). Consumption of raw or heated milk from different species: an evaluation of the nutritional and potential health benefits. Food Control, 42, 188-201. doi:10.1016/j.foodcont.2014.01.045

Eissa, E. A., Mohamed, A. I. A., Yagoub, A. E. A., \& Babiker, E. E. (2010). Physicochemical, microbiological and sensory characteristics of yoghurt produced from goat milk. Livestock Research for Rural Development, 22. Retrieved from http://www . lrrd.org/lrrd22/8/eiss22137.htm

Eissa, E. A., Yagoub, A. E. A., Babiker, E. E., \& Ahmed, I. A. M. (2011). Physicochemical, microbiological and sensory characteristics of yoghurt produced from camel milk during storage. Electronic Journal of Environmental, Agricultural and Food Chemistry, 10(6), 2305-2313.

Farah, Z. (1996). Camel milk: properties and products. St Gallen: Swiss Centre for Development Cooperation in Technology and Management.

Farah, Z. (2011). Encyclopedia of dairy sciences (2nd ed.) In J.W. Fuquay, P.F. Fox \& P.L.H. McSweeney (Ed.), (Chap. Camel milk, pp. 512-517). Amsterdam: Elsevier Ltd.

Faye, B. \& Bonnet, P. (2012). Camel sciences and economy in the world: current situation and perspectives. In 3rd Conference of International Society of Camelid Research and Development, held at Muscat, Sultanate of Oman, January-1 February 2012 (pp. 2-15. 29). Muscat: Sultan Qaboos University.

Gaddour, A., Najari, S., \& Abdennebi, M. (2013). Yoghurt produced from goat milk. Journal of Animal and Veterinary Advances, 12(24), 1700-1703.

Habtegebriel, H. \& Admassu, S. (2016). Optimization of the processing conditions of stirred yoghurt from camel milk using linear programming technique. Food Science and Quality Management, 53, 33-38. Re- 
$62 \mid$ Galeboe et al.

trieved from http://iiste.org / Journals / index.php/FSQM/article/view/31687/0

Haddad, M. A., Al-Qudah, M. M., AbuRomman, S. M., Obeidat, M., \& El-Qudah, J. (2017). Development of traditional jordanian low sodium dairy products. Journal of Agricultural Science, 9(1), 223-230. Retrieved from http://iiste.org/Journals/ index.php/FSQM/article/view/31687/0

Hashim, I. B., Khalil, A. H., \& Habib, H. (2009). Quality and acceptability of a settype yogurt made from camel milk. Journal Of Dairy Science, 92(3), 857-862. doi:10. 3168/jds.2008-1408

Hassan, R. A., El Zubeir, I. E. M., \& Babiker, S. A. (2007). Effect of pasteurization of raw milk and storage temperature on the chemical composition of fermented camel milk. International Journal of Dairy Science, 2(2), 166-171. doi:10.3923/ijds.2007. 166.171

Ibrahem, S. A. \& El Zubeir, I. E. M. (2016). Processing, composition and sensory characteristic of yoghurt made from camel milk and camel-sheep milk mixtures. Small Ruminant Research, 136, 109-112. doi:10 . 1016/j.smallrumres.2016.01.014

Ibrahim, A. H. \& Khalifa, S. A. (2015). The effects of various stabilizers on physiochemical properties of camel's milk yoghurt. Journal of American Science, 11(1), 15-24. Retrieved from http:// www . jofamericanscience. org / journals / am - sci / am110115/003_27636am110115_15_24.pdf

Kavas, N. (2016). Yoghurt production from camel (camelus dramedarius) milk fortified with samphire molasses and different colloids. Mljekarstvo, 66(1), 34-47.

Kgaudi, K. (2014). Milk production potential and major browse species consumed by dromedary camels (camelus dromedarius) in tsabong area, southern kgalagadi district (Doctoral dissertation, Botswana College of Agriculture, Gaborone, Botswana).

Khan, H., Athar, I. H., \& Aslam, M. (2004). Evaluation of cheese prepared by processing camel milk. Pakistan Journal of Zoology, 36(4), 323-326. Retrieved from https: //www.yumpu.com/en/document/view /
30039151/ evaluation- of- cheese- preparedby-processing-camel-zspcompk

Kiros, E., Seifu, E., Bultosa, G., \& Solomon, W. K. (2016). Effect of carrot juice and stabilizer on the physicochemical and microbiological properties of yoghurt. LWTFood Science And Technology, 69, 191-196. doi:10.1016/j.lwt.2016.01.026

Ledenbach, L. H. \& Marshall, R. T. (2009). Compendium of the microbiological spoilage of foods and beverages. In W. Sperber and M. Doyle (Ed.), (Chap. Microbiological spoilage of dairy products, pp. 41-46). New York: Springer Science + Business Media, LLC.

Mehaia, M. A. (1993). Fresh soft white cheese (domiati-type) from camel milk - composition, yield, and sensory evaluation. Journal Of Dairy Science, 76(10), 2845-2855. doi:10.3168/jds.S0022-0302(93)77623-7

Mostert, J. \& Jooste, P. (2002). Dairy microbiology handbook (3rd ed.) In R.K. Robinson (Ed.), (Chap. Quality control in the dairy industry, pp. 655-736). New York: John Wiley and Sons.

Mullaicharam, A. R. (2014). A review on medicinal properties of camel milk. World Journal of Pharmaceutical Sciences, 2(3), 237242. Retrieved from http : / / www . academia . edu / 6245890 / A_review_on_ medicinal_properties_of_Camel_milk

Al-Numair, K. S., Chandramohan, G., \& Alsaif, M. A. (2011). Influence of camel milk on glycoprotein components in streptozotocindiabetic rats. Journal Of Camel Practice And Research, 18(1), 15-20.

Al-Otaibi, M. \& El-Demerdash, H. (2013). Nutritive value and characterization properties of fermented camel milk fortified with some date palm products chemical, bacteriological and sensory properties. International Journal of Nutrition and Food Science, 2(4), 174-180. doi:10.11648/j.ijnfs. 20130204.13

Ramet, J. P. (2001). The technology of making cheese from camel milk (camelus dromedarius). Animal Production and Health Paper, No.113. Rome: Food and Agriculture Organization of the United Nations. 
Quality aspects of camel milk yoghurt $\mid 63$

Richardson, H. G. (1985). Standard methods for the examination of dairy products (6th ed.) Washington DC.: American Public Health Association.

Sahan, N., Yasar, K., \& Hayaloglu, A. A. (2008). Physical, chemical and flavour quality of non-fat yogurt as affected by a betaglucan hydrocolloidal composite during storage. Food Hydrocolloids, 22(7), 12911297. doi:10.1016/j.foodhyd.2007.06.010

Al-Saleh, A. A., Metwalli, A. A. M., \& Ismail, E. A. (2011). Physicochemical properties of probiotic frozen yoghurt made from camel milk. International Journal Of Dairy Technology, 64 (4), 557-562. doi:10.1111/j.14710307.2011.00699.x

Sharma, C. \& Singh, C. (2014). Therapeutic value of camel milk - a review. $A d$ vanced Journal of Pharmacie and Life Science Research, 2(3), 7-13. Retrieved from http : / / ajplronline . org / UploadFile / 635464294846827709.pdf

Shori, A. B. (2015). Camel milk as a potential therapy for controlling diabetes and its complications: a review of in vivo studies. Journal Of Food And Drug Analysis, 23(4), 609-618. doi:10.1016/j.jfda.2015.02.007

Tamime, A. Y. (2006). Fermented milks. Oxford, UK: Blackwell Science Ltd.

Tamime, A. Y. \& Robinson, R. K. (2000). Yoghurt science and technology (2nd ed.) Boca Raton, USA: Woodhead Publishing Ltd and CRC Press LLC.

Yagil, R. (1982). Camels and camel milk. FAO Animal Production and Health Paper 26. Rome, Italy: Food and Agriculture Organization of the United Nations.

Al-Zoreky, N. S. \& Al-Otaibi, M. M. (2015). Suitability of camel milk for making yogurt. Food Science And Biotechnology, 24(2), 601-606. doi:10.1007/s10068-015-0078-z 